\title{
Interpretation of basal ice conditions from radio-echo soundings in the eastern Heimefrontfjella and the southern Vestfjella mountain ranges, East Antarctica
}

\author{
PER HOLMLUND \\ Department of Physical Geography, Stockholm University, S-106 91 Stockholm, Sweden
}

\begin{abstract}
Differences in radio-echoes received from the base of the ice sheet covering two different mountain areas in Dronning Maud Land, East Antarctica, are herein interpreted as differences in the physical properties in the ice and differences in basal conditions. An abnormally strong signal can be caused either by unusually little absorption of radio waves within the ice or by water at the base of the glacier.

One of the areas studied is totally covered by a $400-1400 \mathrm{~m}$ thick ice sheet. The altitude of the surface is about $2800 \mathrm{~m}$ a.s.l. The second area is a nunatak area situated relatively closer to the coast. The ice thickness in the valleys is about $500 \mathrm{~m}$ and the altitude of the surface is about $400 \mathrm{~m}$.

The annual mean surface temperature for the areas is about $-30^{\circ}$ and $-17^{\circ} \mathrm{C}$ respectively. In both cases ice depths are moderate and flow rates low, and it is thus probable that the ice is frozen to the bed.

However, in the colder locality I believe the strong echo is caused by low or negligible rate of mass flux. In the lower area strong bottom echoes are believed to be a cause of negative mass balance at the surface of the blue ice areas. The negative surface mass balance reverses the vertical component of ice flow and it also changes the temperature distribution within the ice. Basal melting conditions may thus occur at locations where the ablation rate is high. This process may also have important implications on the development of land forms under cold ice sheets.
\end{abstract}

\section{INTRODUCTION}

In 1988 a mass balance study was initiated in Dronning Maud Land on East Antarctica (Holmlund and others, 1989). The project included snow coring for accumulation studies and ice velocity surveys and ice depth soundings for balanced flux calculations. The area chosen for this study is an ice stream between the two mountain ranges, Vestfjella and Heimefrontfjella. Mass flux calculations indicate very little flow through the mountain ranges. As much as $60 \%$ of the annual flux through the outlet profile of Veststraumen is balanced by the accumulation of snow between the ranges.

Besides their use in the mass balance study, radio-echo records have been interpreted in order to distinguish between parts of the ice sheet frozen to the ground and areas where the basal ice is at the pressure melting point.

Radio-echo soundings were carried out in a nunatak area in Vestfjella and in an ice covered part of Heimefrontfjella, Dronning Maud Land (Fig. 1). The strength of the registrated radio-echoes varied about $10 \mathrm{~dB}$ at similar depths indicating differences in the basal thermal conditions of the ice and/or differences in the absorption of radio waves within the ice.

The strength of a reflected pulse is governed by modulations within the transmitter and/or differences in the dielectric constant, or the relative permittivity in the ice. The difference in dielectric constants between ice and water is about 14 times larger than the difference between constants for ice and rock (Ewan Smith and Evans, 1972). Small fractions of water at an interface influences the phase and strength of the reflecting signal (Walford and others, 1986). Different rock types do not have significantly different dielectric constant and thus do not have a primary influence on the strength of the reflected pulse. A frozen till or sediment layer may, however, weaken the echo by making the interface less sharp, smearing the changes in physical properties over more than a wavelength.

In Antarctica, where ice depths generally are large, reflected radio-echo pulses are weak. The absorption of signal strength is on the order of $1 \mathrm{~dB} 100 \mathrm{~m}^{-1}$ for $150 \mathrm{MHz}$ in pure ice (Ewan Smith and Evans, 1972). The intense reflection from a subglacial waterspot or water film will show up very clear. However, at high altitudes where temperatures are low and no blue ice areas occur, similar bed echoes may occur where the rate of snow accumulation is low. This cannot be explained by basal melting but rather by a higher permittance of radiowaves.

The radio-echo soundings were made within the frame of the Swedish Antarctic Research Programme (SWEDARP) in January 1989 and 1992. 


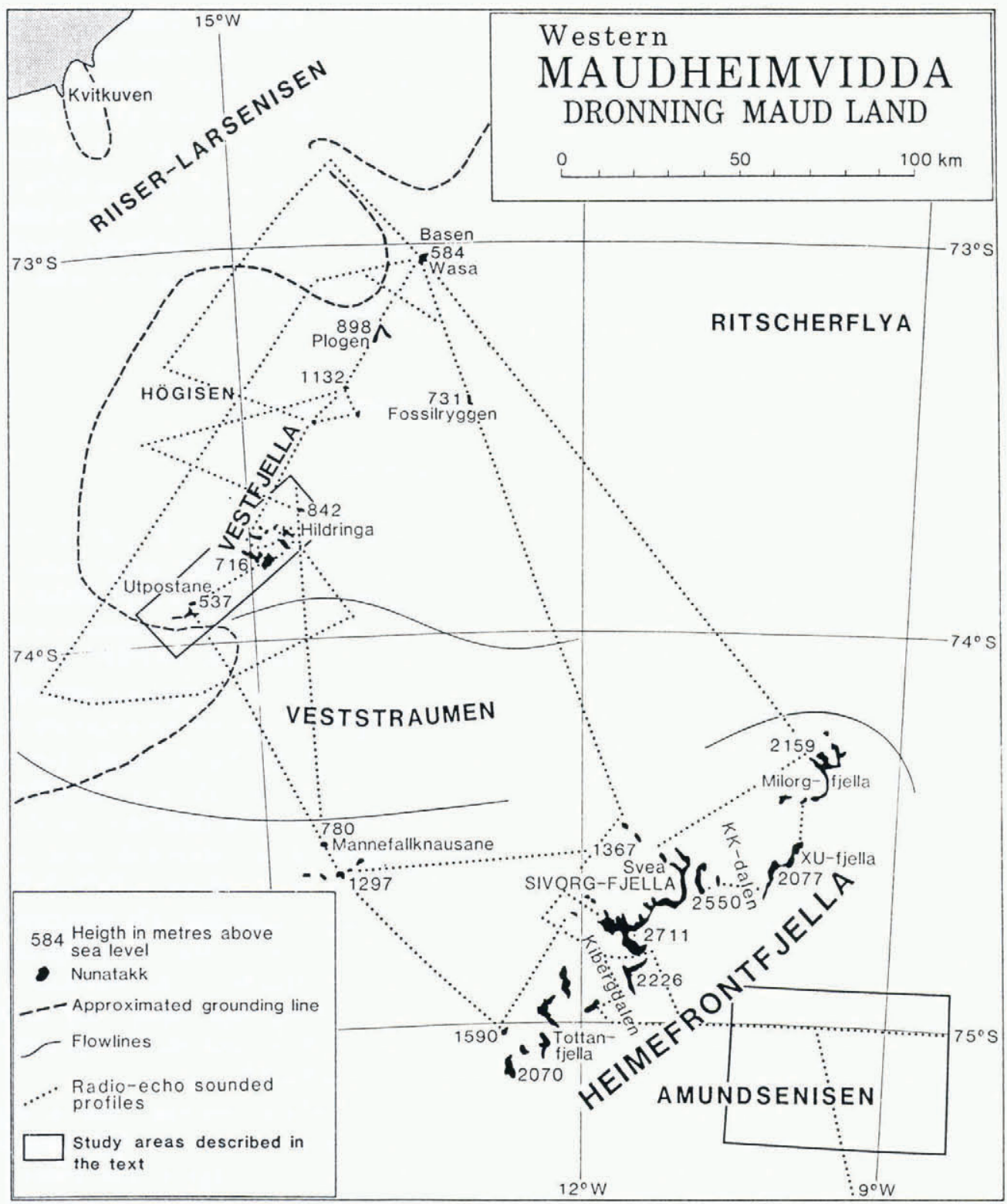

Fig. 1. Location map, East Antarctica.

\section{PHYSICAL SETTINGS}

\section{Southern Vestfjella}

The Vestfjella mountain range is situated in Dronning Maud Land $\left(73-74^{\circ} \mathrm{S}, 13-16^{\circ} \mathrm{W}\right)$, East Antarctica (Fig. 1). The whole range was mapped by the use of aerial photographs taken during the Norwegian-British-Swedish expedition 1949/51 (Gjaever and Schytt, 1963) and later from Landsat images (IfAG 1988). Data on the bottom topography are published by Orheim (1986) and Holmlund and others (1989). The geography is described by Jonsson (1988). The area is characterized by blue ice areas (Fig. 2).

Ice is drained through the area into Veststraumen which is situated southeast from the range. The ice cap Högisen, northwest of the range, drains partly through the area. The general ice flow direction is thus south-east from Högisen through the nunatak area and then turning to southwest in Veststraumen. Though the ice depth in southern Vestfjella is about $500 \mathrm{~m}$ crevassing in the area indicates a significant movement.

In southern Vestfjella the ice surface is at about $400 \mathrm{~m}$ and the highest summit is the $841 \mathrm{~m}$ Hildringa.

\section{Eastern Heimefrontfjella}

The Heimefrontfjella mountain range is situated about $150 \mathrm{~km}$ southeast of the Vestfjella. The range is about $150 \mathrm{~km}$ long and reduces the outflow of ice from Amundsenisen to Maudheimvidda situated downstream. The drop in elevation is about $1500 \mathrm{~m}$. The highest mountain, Paalnibba, reaches $2711 \mathrm{~m}$ a.s.l. East of the range $\left(75^{\circ} 10^{\prime} \mathrm{S}, 10^{\circ} 30^{\prime} \mathrm{W}\right.$ and $\left.8^{\circ} 30^{\prime} \mathrm{W}\right)$ there are two subglacial mountains, covered by only some hundreds of meters of ice. They are visible at satellite images as an uneven wrinkled surface (IfAG, 1988, 1989). The snow surface is rough with sastrugi up to $1 \mathrm{~m}$. The annual rate of snow accumulation is probably low in this area as the flux rates in the Heimefrontfjella valleys draining the area 


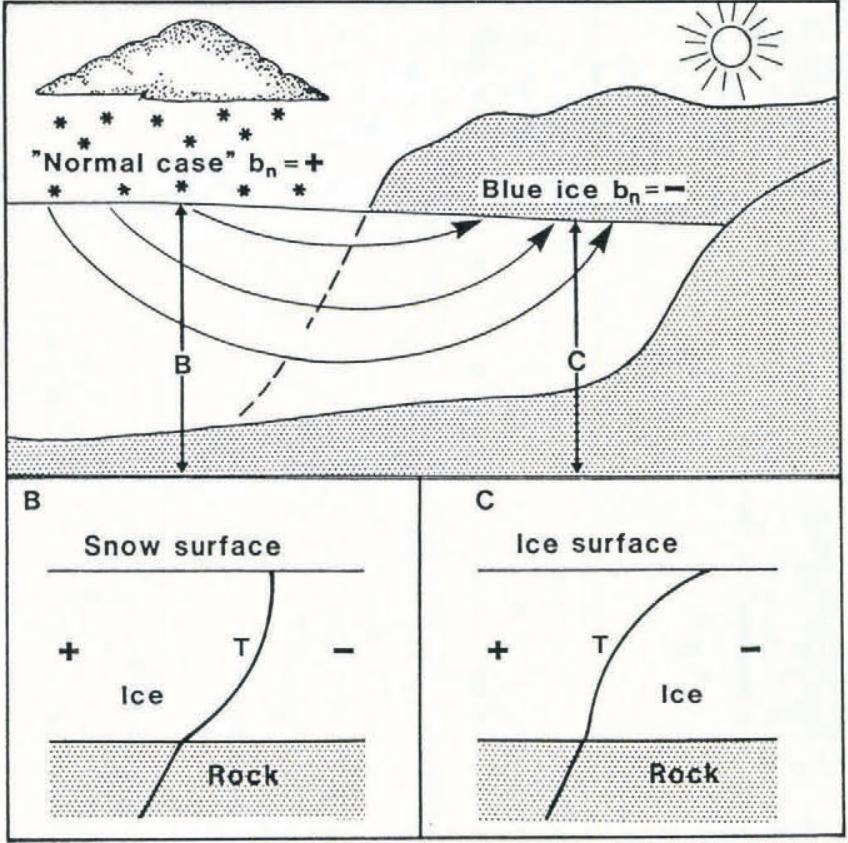

Fig. 2. Generalized figure showing $A$, mass balance conditions, bn, and a simplified curve, $T$, showing $a$ probable temperature distribution in an ice sheet $B$, and in a blue ice area $C$.

are low. Accumulation, as measured in a bore hole in a nearby site, gave an annual rate of $104 \mathrm{~mm}$ (Isaksson, 1992). This area is an extension of the saddle-like ice divide from the Dome $\mathrm{F}$ ending at Heimefrontfjella.

At Amundsenisen there are few signs of crevasses, in contrast to the valleys in Heimefrontfjella where the ice is heavily crevassed while dropping about $1000 \mathrm{~m}$ in altitude.

The northernmost part of Heimefrontfjella, called Milorgfjella, was first observed during the Schwabenland expedition in 1938/39. The whole range was later mapped and named during the Norwegian-BritishSwedish expedition 1949/51 (Gjaever and Schytt, 1963). The range contains four groups of mountains separated by valleys. The most prominent valley is called Kibergdalen. The bed topography in Heimefrontfjella has been mapped by Holmlund (Herzfeld and Holmlund, 1988, 1990; Hoppe and Thyssen, 1988).

\section{TEMPERATURE DISTRIBUTION IN ICE SHEETS}

Most of the East Antarctic ice sheet has a positive surface mass balance, giving higher velocities near the coast. This implies a generally downward vertical flux (Fig. 2A). This transportation of cold ice and snow influences the temperature distribution within the ice in the sense that the thermal gradient is flatter than the geothermal gradient in the bedrock beneath. The gradient is, however, positive and steep close to the bottom because of heat released by internal deformation and because of the influx of heat from the underlying bedrock (Fig 2B).

If the mass balance is negative, as it is on blue ice fields in nunatak areas, the temperature distribution is significantly different (Fig. 2A and $\mathrm{C}$ ). The net loss of mass at the surface is compensated by a vertical movement upwards in order to preserve a balanced state. The gradient of the temperature profile is steep close to the surface and more gently sloping close to the bottom (Fig. 2C), as on a subpolar glacier (Hooke and others, 1983). The governing variables are the rate of ablation and the air temperature. The base of ice sheets at low altitudes can thus probably reach the pressure melting point beneath blue ice areas even if the ice depth is moderate.

\section{FIELD SURVEYS}

\section{Equipment}

The radar equipment used is a continuous wave-step frequenzy radar (K-band radar based on a HewlettPackard network analyzer HP 8753B). The system is developed by the Royal Norwegian Council for Scientific and Industrial Research (NTNF). The radar transmits 201 frequencies equally spaced around an adjustable centre frequency and with an adjustable bandwidth from $0.3 \mathrm{MHz}$ to $3 \mathrm{GHz}$. In this study two different centre frequencies were used, 155 and $345 \mathrm{MHz}$. The radar was pulsed in time using a range-gate so as to eliminate the direct leakage signal between the antennae.

Data were recorded on a IBM P-70 387 computer with a 60 Mbyte hard disk. The maximum sampling rate in a profiling mode was $0.6 \mathrm{~s}$. Data was stored in a optical disk unit (Verbatim). The software, based on the scientific software tool Asyst, was developed by the Environmental Surveillance Technology Programme (PFM) at the NTNF.

The $150 \mathrm{MHz}$ antenna was a dipole with an aluminum reflector and the $345 \mathrm{MHz}$ antenna was a Yagi type with 6 elements. The radar equipment was operated from a MD-500 helicopter and from a Hägglund snow vehicle.

\section{Airborne surveys}

The radar equipment was installed on an aluminum frame in the back seat of the helicopter and was operated from the co-driver seat. Variable speeds between 50 and 90 knots were used for different kind of surveys. The flying altitude was normally $10 \mathrm{~m}$.

A Trimble Pathfinder Professional (GPS-system) was used for navigation and for storing position data. Position and altitude was logged each second.

Southern Vestfjella was covered by radio-echo sounding during several visits during the SWEDARP 1988/89 and 1991/92 expeditions. The central Heimefrontfjella was surveyed by a smaller number of radioecho profiles during both expeditions.

\section{Ground based surveys}

The equipment was installed in the front cabin of a Hägglunds snow vehicle and the $150 \mathrm{MHz}$ dipole antennaes with reflectors were mounted on a $6 \mathrm{~m}$ long pole fixed to the roof of the vessel. The dipoles were thus situated about $1 \mathrm{~m}$ above the ground. The sampling 


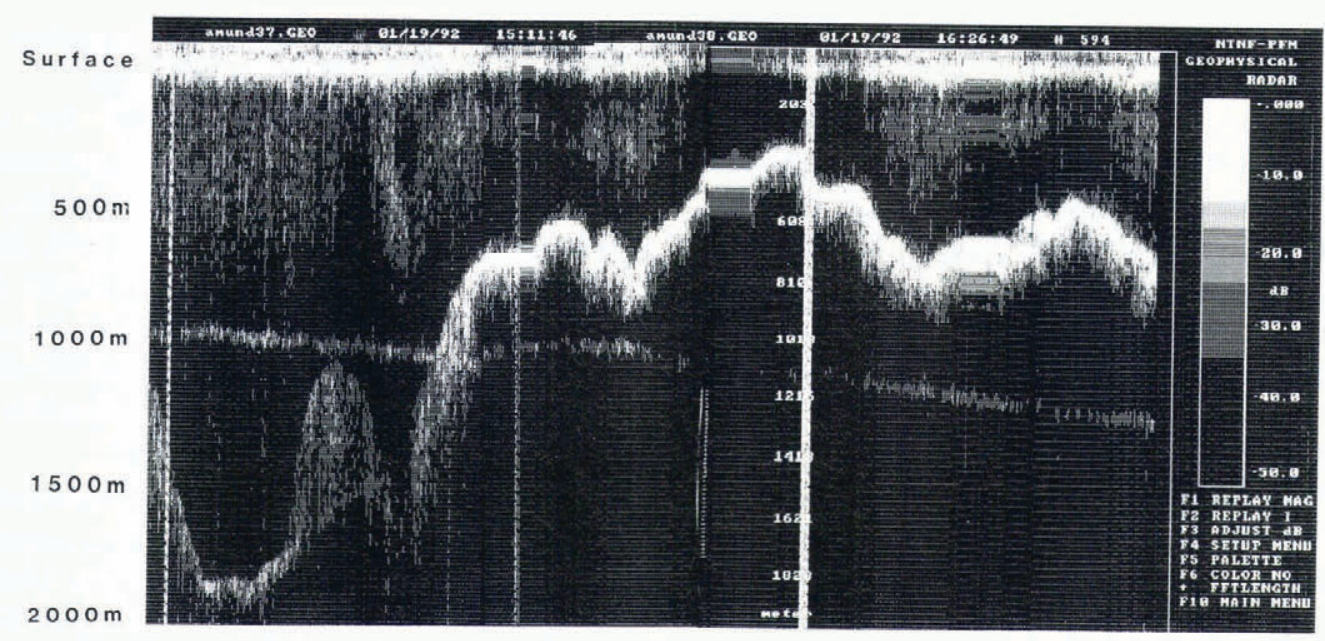

Fig. 3. Radio-echo record showing a subglacial mountain range southeast from Heimefrontfjella. The length of the profile is about $20 \mathrm{~km}$ and ice depths are given in metres. Note that internal layers are lacking. The profile was surveyed in January 1992.

interval was generally $10 \mathrm{~s}(30 \mathrm{~m})$. Positions were logged using the Trimble Pathfinder Professional system with time spacing equal to the sampling speed of the echo sounder. This constellation of equipment was used only in the Heimefrontfjella range for logistic reasons.

\section{RESULTS}

In both areas studied the radar recordings received show relatively strong echoes from the base of the ice sheet and few or no internal echoes. The signals received were generally strong and clear and at one site, beneath a supraglacial lake, the signals were very strong indicating the existence of melt water at the base. This supraglacial lake close to the nunatak Skansen has been described by Jonsson (1988) and a more full description is in preparation by Jonsson. Snow layering was not surveyed at Vestfjella but the blue ice clearly indicates a net loss of mass from the surface.

Eastern Heimefrontfjella was visited and surveyed in January 1992. The bed topography is mirrored by the wrinkles that can be observed in the satellite images (IfAG, 1988). The reflected signal was 10-20 dB stronger at this site in comparison with nearby areas to the east and to the south. East and south of the area internal layers were surveyed down to a depth of approximately $500 \mathrm{~m}$. These internal layers were not visible in the study area (Fig. 3).

\section{DISCUSSION}

In order to use radio-echo technique to distinguish wetbased areas from frozen-bcd areas attention must be paid to the rate of scattering within the ice. Variation in the ability for radiowaves to penetrate the ice may give misleading information. There is a significant risk to overestimate the extension of wet based areas. However, data suggest changes of $10-20 \mathrm{~dB}$ in strength at 1500
$2000 \mathrm{~m}$ to be caused by changes in the permittance of radiowaves within the ice.

In eastern Heimefrontfjella there is no reason to believe that the ice sheet is wet-based as the movement is slow and the temperature is low. Thus, relative strong bed echoes may indicate basal melting condition, low accumulation rate or both. In addition to accumulation measurements, radio-echo soundings may give us quantitative information on variations in accumulation rates if internal layers can be identified and mapped over large distances. Radio-echo soundings may also give qualitative views of the dynamics in the area studied as ice divides may show up as areas with low rates of internal scattering.

\section{GONCLUSION}

The areas with strongly reflecting spots, or strong reflection in general, occur beneath blue ice areas or areas with little mass turnover. A negative mass balance influences the flow and the thermal distribution within the ice. Blue ice at low altitudes, with high ablation rates may cause a significant warm-up of the ice body because of the vertical up-going movement.

However, at high altitudes where no nunataks are visible above the snow surface and where there is no blue ice, but a low rate of mass turnover, the echoes also get strong in comparison to neighbouring areas with higher accumulation rates. To differentiate wet-based areas from cold-based areas in radio-echo records true changes in the dielectric constant must be distinguished. In order to do this special attention must be paid to variations in the relative permittity within the ice.

\section{ACKNOWLEDGEMENTS}

This project was financed by the Swedish Natural Science Research Council (NFR) and the Department of Physical Geography at Stockholm University. The logistics were 
kindly supplied by the Swedish Polar Research Secretariat. I am very grateful to the Norwegian Council for Scientific and Industrial Research (NTNF-PFM) for stimulating collaboration and help with radar hardware and software. Thanks are also due to the Swedish Authority for Spent Nuclear Waste (SKN), Nord-Optik AB (NOAB), IBM and Verbatim.

\section{REFERENCES}

Gjæver, J. and V. Schytt. 1963. General report of the expedition. Norwegian-British-Swedish Antarctic Expedition, 1949-52. Sci. Results, VI, Part 3.

Gjessing, Y. and B. Wold. 1986. Absolute movements, mass balance and snow temperatures of the RiiserLarsenisen Ice Shelf, Antarctica. Nor. Polarinst. Skr. 187, 23-31.

Herzfeld, U. C. and P. Holmlund. 1988. Geostatistical analyses of radio-echo data from Scharffenbergbotnen, Dronning Maud Land, East Antarctica. Z. Gletscherkd. Glazialgeol., 24(2), 95-110.

Herzfeld, U.C. and P. Holmlund. 1990. Geostatistics in glaciology: implications of a study of Scharffenbergbotnen, Dronning Maud Land, East Antarctica. Ann. Glaciol., 14, 107-110.

Holmlund, P., E. Isaksson and W. Karlén. 1989. Massbalans, isrörelse och isdynamik. Preliminära resultat från fältsäsongen 1988/89 i Vestfjella och Heimefrontfjella, V. Dronning Maud Land, Antarktis. Stockholms Universitet. Naturgeografiska Institutionen. Forskningsrapport 73.

Hooke, R. LeB., J. E. Gould and J. Brzozowski. 1983. Near-surface temperatures near and below the equili- brium line on polar and subpolar glaciers. $Z$. Gletscherkd. Glazialgeol., 19(1), 1-25.

Hoppe, H. and F. Thyssen. 1988. Ice thickness and bedrock elevation in western Neuschwabenland and Berkner Island, Antarctica. Ann. Glaciol., 11, 42-45.

Institut für Angewandte Geodäsie. 1988. Ritscherhochland, SS 28-30. Satellite image map 1:1000000. Frankfurt am Main, Institut für Angewandte Geodäsie.

Institut für Angewandte Geodäsie. 1989. Heimefrontfjella. Satellite image map 1:250000. Frankfurt am Main, Institut für Angewandte Geodäsie.

Isaksson, E. 1992. Spatial and temporal patterns in snow accumulation and oxygen isotopes, western Dronning Maud Land, Antarctica. Stockholms Universitet. Naturgeografiska Institutionen. Forskningsrapport 87.

Jonsson, S. 1988. Observations on the physical geography and glacial history of the Vestfjella nunataks in western Dronning Maud Land, Antarctica. Stockholms Universitet. Naturgeografiska Institutionen. Forskningsrapport 68.

Orheim, O. 1986. Flow and thickness of RiiserLarsenisen, Antarctica. Nor. Polarinst. Skr. 187, 5-22.

Orheim, O. and 6 others. 1986. Oxygen isotopes and accumulation rates at Riiser-Larsenisen, Antarctica. Nor. Polarinst. Skr. 187, 33-47.

Smith, B. M.E. and S. Evans. 1972. Radio echo sounding: absorption and scattering by water inclusion and ice lenses. 7. Glaciol., 11(61), 133-146.

Walford, M.E. R., M. I. Kennett and P. Holmlund. 1986. Interpretation of radio echoes from Storglaciären, northern Sweden. J. Glaciol., 32(110), 39-49.

The accuracy of references in the text and in this list is the responsibility of the author, to whom queries should be addressed. 